DOI: $10.19195 / 0137-1134.117 .2$

\author{
IZABELA FLORCZAK \\ ORCID: 0000-0003-3167-3382 \\ Uniwersytet Łódzki
}

\title{
UMOWA O POMOCY PRZY ZBIORACH - NOWA PODSTAWA PRAWNA ZATRUDNIENIA
}

\begin{abstract}
Abstrakt: Kreowana od lat polityka rynku pracy zdaje się mieć na względzie promowanie zatrudnienia pracowniczego ponad zatrudnienie cywilnoprawne. Dokładnie odwrotny kierunek wyznacza umowa o pomocy przy zbiorach. Racjonalność jej wprowadzenia do systemu prawnego thumaczona jest względami ekonomicznymi - koniecznością pomocy rolnikom przy pracach cechujących się wzmożoną intensywnością sezonową. Istotne jest zatem omówienie zakresu jej stosowania (zarówno w aspekcie przedmiotowym, jak i podmiotowym) oraz warunków, w jakich pracę mają świadczyć pomocnicy rolników. Ich zróżnicowanie względem warunków pracy innych osób zatrudnionych powinno być racjonalnie uzasadnione poprzez aksjologiczne umotywowanie.
\end{abstract}

Słowa kluczowe: zatrudnienie przy zbiorach, pomocnik rolnika, dezintegracja ochrony pracy, zatrudnienie cywilnoprawne

\section{WPROWADZENIE}

Prawo zatrudnienia, w zakresie podmiotowo-przedmiotowym rozumiane znacznie szerzej aniżeli samo prawo pracy ${ }^{1}$, od lat boryka się z wieloma trudnościami. Wiążą się one między innymi ze zmieniającym się paradygmatem pracy, ukrywaniem rzeczywistej więzi pracowniczej pod postacią zatrudnienia cywilnoprawnego ${ }^{2}$ oraz tym, że nie ma rozwiązań systemowych gwarantujących przestrzeganie istniejących rozwiązań prawnych ${ }^{3}$. Bez wątpienia zatrudnieniem, które gwarantuje większą niż

${ }^{1}$ O istocie prawa zatrudnienia, jego charakterystyce i wyodrębnieniu zob. M. Gersdorf, Prawo zatrudnienia, Warszawa 2013.

2 Wskazuje na to między innymi uzasadnienie projektu ustawy, której mocą stosowanie przepisów o minimalnym wynagrodzeniu rozszerzono na umowy zlecenia. Druk nr 600 Sejmu VIII kadencji.

3 Warto wskazać, że istnieje wiele środków służących przeciwdziałaniu zatrudnieniu cywilnoprawnemu w miejsce pracowniczego. Więcej I. Florczak, Status prawny osób świadczących pracę w ramach umownego zatrudnienia nietypowego, Łódź 2017, s. 61 n. 
zatrudnienie cywilnoprawne ochronę osobom świadczącym pracę, jest zatrudnienie pracownicze. Przy kształtowaniu polityki zatrudnienia służącej ochronie osób pracujących to właśnie ono powinno być promowane przez ustawodawcę.

Konstrukcja prawna, jaką jest umowa o pomocy przy zbiorach, zdaje się realizować ów postulat w znaczeniu jednak tak ograniczonym, że niemal niedostrzegalnym, legalizując przy tym stan do tej pory uznawany za sprzeczny z prawem. Analiza regulacji umowy o pomocy przy zbiorach wymaga, poza kontekstem czysto prawnym, umiejscowienia jej w polityce zatrudnienia, realizowanej zarówno przez ustawodawcę krajowego, jak i na poziomie ponadnarodowym.

\section{RATIO LEGIS WPROWADZENIA NOWEJ PODSTAWY PRAWNEJ ZATRUDNIENIA}

Zgodnie z uzasadnieniem ${ }^{4}$ do projektu ustawy ${ }^{5}$ wprowadzającej do polskiego porządku prawnego umowę o pomocy przy zbiorach racjonalność jej obowiązywania motywowana była w szczególności tym, że sadownictwo i ogrodnictwo to działy rolnictwa, w których największy nakład pracy przypada na okres zbiorów — od maja do listopada. Zatem prace te mają charakter sezonowy, co uniemożliwia stosowanie zasad zatrudnienia o trwałym charakterze. W uzasadnieniu do projektu ustawy wskazywano ponadto, że plantatorzy owoców i warzyw potrzebują w trakcie dojrzewania owoców i warzyw znacznej liczby osób do pomocy przy zbiorach, a argumentem przemawiającym za przygotowaniem regulacji w zakresie umowy o pomocy przy zbiorach miało być nagminne stosowanie przy pracach w rolnictwie umów o dzieło, które nie przystają do charakteru pracy osób zatrudnionych przy zbiorach i nie są one oskładkowane w stopniu dostatecznym. Tym samym celem tej konstrukcji było spełnienie dwóch głównych założeń:

- ułatwienia dokonywania zbiorów w sadownictwie i ogrodnictwie przez stworzenie konstrukcji prawnej umożliwiającej zatrudnianie osób do wykonywania tych $\mathrm{prac}^{6}$;

— poprawy sytuacji prawnej osób zatrudnionych przy pracach sezonowych w wybranych sektorach rolnictwa (sadownictwie i ogrodnictwie).

${ }^{4}$ Druk nr 2334 Sejmu VIII kadencji.

5 Ustawa z dnia 13 kwietnia 2018 roku o zmianie ustawy o ubezpieczeniu społecznym rolników oraz niektórych innych ustaw, Dz.U. poz. 858.

${ }^{6} \mathrm{~W}$ uzasadnieniu do projektu ustawy podkreślono, że ma ona na celu również znaczne ograniczenie administracyjnych obowiązków rolnika. Projektodawca nie podjął natomiast choćby próby wskazania powodów, jakie miałyby racjonalizować stosowanie takich ułatwien. 


\section{STRONY, FORMA I PRZEDMIOT UMOWY O POMOCY PRZY ZBIORACH}

Umowę o pomocy przy zbiorach zawierają rolnik (jako podmiot zatrudniający) i pomocnik rolnika (jako podmiot zatrudniany). Rolnikiem, w rozumieniu ustawy o ubezpieczeniu społecznym rolników ${ }^{7}$, jest pełnoletnia osoba fizyczna, zamieszkująca i prowadząca na terytorium Rzeczypospolitej Polskiej, osobiście i na własny rachunek działalność rolniczą w pozostającym w jej posiadaniu gospodarstwie rolnym, w tym w ramach grupy producentów rolnych, a także osoba, która przeznaczyła grunty prowadzonego przez siebie gospodarstwa rolnego do zalesienia. Zgodnie $\mathrm{z}$ art. 6 pkt 2a usr pomocnikiem rolnika jest osoba pełnoletnia, z którą rolnik zawarł umowę o pomocy przy zbiorach. Zdaniem Mariusza Miąski wymóg osiągnięcia pełnoletności przez pomocnika rolnika jest związany między innymi z charakterem pracy w rolnictwie i wynika z potrzeby zachowania zwiększonej ostrożności podczas prac lub z potencjalnie znacznego ciężaru przenoszonych produktów rolnych. Zdaniem autora pełnoletniość pomocnika ma stanowić jeden z elementów podnoszących poziom bezpieczeństwa pracowników $\mathrm{w}$ pracy ${ }^{8}$. Teza ta pozostaje $\mathrm{w}$ oczywistej sprzeczności z pozbawieniem pomocnika rolnika prawa do bezpiecznych i higienicznych warunków pracy, o czym mowa będzie w dalszej części.

Zgodnie $\mathrm{z}$ art. $91 \mathrm{~b}$ usr umowę o pomocy przy zbiorach zawiera się na piśmie przed rozpoczęciem świadczenia pomocy przy zbiorach. Istotne jest określenie przedmiotu umowy o pomocy przy zbiorach. Świadczenie pomocy przy zbiorach dotyczy produktów rolnych należących do jednej z kategorii dalej wymienionych i obejmuje czynności polegające na:

— zbieraniu chmielu, owoców, warzyw, tytoniu, ziół lub roślin zielarskich;

— usuwaniu zbędnych części roślin;

- klasyfikowaniu lub sortowaniu zerwanych lub zebranych chmielu, owoców, warzyw, tytoniu, ziół lub roślin zielarskich, lub

- wykonywaniu innych czynności mających na celu przygotowanie chmielu, owoców, warzyw, tytoniu, ziół lub roślin zielarskich do transportu, przechowywania lub sprzedaży, lub związanych z pielęgnowaniem i poprawą jakości plonów.

W umowie o pomocy przy zbiorach określa się zakres czynności wykonywanych na podstawie tej umowy przez pomocnika rolnika.

7 Ustawa z dnia 20 grudnia 1990 roku o ubezpieczeniu społecznym rolników, tekst jedn. Dz.U. z 2019 r. poz. 299 z późn. zm. (dalej: usr).

8 M. Miąsko, Analiza charakterystyki umowy o pomocy przy zbiorach (ujęcie komparatystyczne), „Studia z Zakresu Prawa Pracy i Polityki Społecznej” 25, 2018, nr 2, s. 149. Warto przy tym wskazać, że w dalszym toku wywodu (s. 152) autor dowodzi, uzasadniając nieprzyznanie pomocnikom rolnika prawa do bhp, że nie sposób zakwestionować występowania wśród wielu różnych prac w rolnictwie także prac ciężkich, lecz co do zasady nie w tych obszarach, które zostały objęte przedmiotem umowy o pomocy przy zbiorach. Tym samym przytoczone przez autora racje wzajemnie się wykluczają. 
Zgodnie z 91a ust. 1 usr pomoc przy zbiorach może obejmować:

— produkty rolne należące do sektora, o którym mowa w art. 1 ust. 2 lit. f, i oraz n rozporządzenia Parlamentu Europejskiego i Rady (UE) nr 1308/2013 z dnia 17 grudnia 2013 roku ustanawiającego wspólną organizację rynków produktów rolnych oraz uchylającego rozporządzenia Rady (EWG) nr 922/72, (EWG) nr 234/79, (WE) nr 1037/2001 i (WE) nr 1234/20079,

— pozostałe zioła i rośliny zielarskie.

Do pierwszej z wskazanych kategorii należą chmiel, owoce i warzywa, tytoń. W ramach osobnej grupy ustawodawca wymienił pozostałe zioła i rośliny zielarskie, nadając obu kategoriom wspólną nazwę „chmiel, owoce, warzywa, tytoń, zioła i rośliny zielarskie". Na marginesie warto zaznaczyć, że ustawodawca w uzasadnieniu do projektowanej ustawy wskazywał, że umowę o pomocy przy zbiorach będzie można wykorzystywać do zbioru pieczarek. Jednakże pieczarka, jako grzyb, nie mieści się w żadnej z wspomnianych kategorii.

\section{CHARAKTER PRAWNY UMOWY O POMOCY PRZY ZBIORACH}

W przepisie art. 91a ust. 4 usr ustawodawca przesądził o cywilnoprawnym charakterze umowy o pomocy przy zbiorach, wskazując, że wykonywanie czynności jej przynależnej nie oznacza zatrudnienia w rozumieniu kodeksu pracy ${ }^{10}$. Tym samym ustawodawca wykluczył możliwość uznania czynności wykonywanych $\mathrm{w}$ ramach pomocy przy zbiorach za wykonywane $\mathrm{w}$ ramach zatrudnienia pracowniczego, bez względu na rzeczywiste warunki zatrudnienia i świadczenia pracy. Z góry rozstrzygnięto, że czynności takie są zawsze zatrudnieniem cywilnoprawnym, bez względu choćby na rzeczywiste podporządkowanie osoby zatrudnionej podmiotowi zatrudniającemu.

Umowy cywilnoprawne są częścią prawa prywatnego, podczas gdy ustawa o ubezpieczeniu społecznym rolników należy do prawa publicznego. Zastosowano zatem konstrukcję regulowania $\mathrm{w}$ akcie prawnym $\mathrm{z}$ obrębu prawa publicznego umowy przynależącej do prawa prywatnego. Przepis art. 91r usr wprowadza regułę, zgodnie z którą w zakresie nieuregulowanym w rozdziale dotyczącym umowy o pomocy przy zbiorach stosuje się przepisy kodeksu cywilnego. Jest to niepodważalny dowód erozji prawa umów przez wkraczanie w jego autonomię źródeł o charakterze publicznoprawnym.

Decydując o tym, czy pomoc przy zbiorach jest świadczeniem nastawionym na rezultat (umowa rezultatu), czy samą jego staranność (umowa starannego działania), wydaje się, że to raczej umowa starannego działania. W umowie określa się ,zakres

9 Dz. Urz. UE L 347, 20 grudnia 2013, z późn. zm., s. 671.

${ }^{10} \mathrm{Na}$ marginesie warto jedynie wskazać, że kodeks pracy nie definiuje pojęcia zatrudnienia, mimo że się posługuje nim wielokrotnie. O pojęciu zatrudnienia więcej I. Florczak, Zatrudnienie jako kategoria prawna, „Gdańsko-Łódzkie Roczniki Prawa Pracy i Prawa Socjalnego”2013, nr 3, s. 51-62. 
czynności wykonywanych na podstawie tej umowy przez pomocnika rolnika", a nie pracę, jaka ma być wykonana. Choć nie można zaprzeczyć, że czynności wykonywane w ramach pomocy przy zbiorach związane są z osiągnięciem określonego rezultatu (na przykład zbieranie chmielu), jednakże istotna jest ciągłość czynności (zbieranie), nie zaś efekt (zebranie). Nie pozostaje to zgodne z założeniami, jakie przyświecały ustawodawcy przy wprowadzaniu umowy o pomocy przy zbiorach do ustawy o ubezpieczeniu społecznym rolników. Nowa podstawa prawna miała bowiem przeciwdziałać stosowaniu umów o dzieło do wykonywania takich prac. Kwalifikując prace te jako prace starannego działania (nie rezultatu), ustawodawca przesądził, że z powodzeniem mogły być one wykonywane na podstawie umów o świadczenie usług, do których stosuje się przepisy o zleceniu (nie umów o dzieło), gwarantując minimalny stopień ochrony osobom zatrudnionym (między innymi prawo do bhp, prawo do minimalnego wynagrodzenia za pracę). Tym samym możliwe było ograniczenie patologicznych sytuacji (stosowania umów o dzieło) przez sankcjonowanie obowiązującego prawa - klasyfikowanie stosunków prawnych jako umów o świadczenie usług, do których stosuje się przepisy o zleceniu. Ponadto jeśli strony umowy określą jako jej przedmiot rezultat (na przykład zebranie, nie zbieranie), nie będzie można uznać takiej umowy za umowę o pomocy przy zbiorach. Umowa rezultatu (umowa o dzieło) nie będzie kwalifikowana, wbrew intencjom ustawodawcy, jako umowa o pomocy przy zbiorach.

Czynności wykonywane przez pomocnika rolnika mają charakter osobisty zgodnie $\mathrm{z}$ art. 91 usr pomocnik rolnika jest obowiązany do osobistego świadczenia pomocy przy zbiorach. Pomoc przy zbiorach ma z zasady czasowy charakter, co wynika jednoznacznie z treści art. 91a ust. 1 usr. Czasowość zatrudnienia jest ściśle związana z osobą pomocnika rolnika. Łączny czas świadczenia pomocy przy zbiorach na podstawie umów o pomocy przy zbiorach zawartych przez jednego pomocnika rolnika nie może przekroczyć 180 dni w roku kalendarzowym. Aby zweryfikować ową okoliczność, pomocnik rolnika przed zawarciem umowy o pomocy przy zbiorach składa oświadczenie o liczbie dni w danym roku kalendarzowym, przez które świadczył pomoc przy zbiorach na podstawie umów o pomocy przy zbiorach zawartych z innymi rolnikami. Ustawa nie przewiduje sankcji za naruszenie okresowego charakteru wykonywania pracy pomocnika rolnika.

\section{GWARANCJE Z ZAKRESU UBEZPIECZEŃ SPOŁECZNYCH I OCHRONY PRACY (NIE)PRZYSŁUGUJĄCE POMOCNIKOWI ROLNIKA}

Zdecydowanie węższy katalog dotyczy tych obszarów, w którym pomocnikom rolnika zagwarantowano uprawnienia z zakresu ubezpieczeń społecznych ${ }^{11}$

11 Ze względu na ograniczone możliwości rozległości tekstu pominięto uwagi związane ze sposobem obliczania i opłacania składek na ubezpieczenie społeczne rolników za pomocników rolników. 
i ochrony pracy aniżeli tych, których im nie zagwarantowano. Wśród gwarancji przysługujących pomocnikom rolnika na powyższych płaszczyznach należy wymienić podleganie ubezpieczeniu wypadkowemu, chorobowemu i macierzyńskiemu w zakresie jednorazowego odszkodowania $\mathrm{z}$ tytułu stałego lub długotrwałego uszczerbku na zdrowiu albo śmierci wskutek wypadku przy pracy rolniczej lub rolniczej choroby zawodowej oraz zasiłku chorobowego. Tym samym pomocnik rolnika nie podlega ubezpieczeniu emerytalnemu. W zakresie zagadnień najistotniejszych z punktu widzenia funkcji ochronnej prawa pracy warto wskazać, że pomocnik rolnika pozbawiony jest też gwarancji w zakresie prawa do minimalnego wynagrodzenia, prawa do bezpiecznych i higienicznych warunków pracy, prawa do urlopu, prawa do przerw w pracy, w tym do minimalnego odpoczynku.

Prawo do minimalnego wynagrodzenia nie zostało przyznane pomocnikowi rolnika mimo negatywnej oceny przez ustawodawcę stanów faktycznych, w których osoby zatrudnione na podstawie umów o świadczenie usług, do których stosuje się przepisy o zleceniu, nie otrzymywały wynagrodzenia minimalnego ${ }^{12}$. Prawo do bezpiecznych i higienicznych warunków pracy nie zostało przyznane pomocnikom rolnika, mimo że jest to prawo zagwarantowane każdemu mocą art. 66 ust. 1 Konstytucji ${ }^{13}$. Co także istotne - prace wykonywane w sadownictwie i ogrodnictwie cechuje znaczne ryzyko związane z negatywnymi skutkami braku zapewnienia bezpiecznych i higienicznych warunków pracy. Tym bardziej prawo do bhp powinno być zagwarantowane przy wykonywaniu tego rodzaju czynności.

Niezagwarantowanie pomocnikom rolników jakichkolwiek przerw w pracy oraz płatnych okresów jej nieświadczenia może prowadzić do ponadprzeciętnej eksploatacji sił pomocnika rolnika przez $180 \mathrm{dni}$ w roku. Uzasadnieniem braku prawnie zagwarantowanych okresów odpoczynku osobom wykonującym pracę na podstawie umów prawa cywilnego jest fakt, że osoby te same organizują proces swojej pracy. Tym samym samodzielnie decydują, kiedy pracują, kiedy nie pracują (odpoczywają). Czy jednak można tę tezę zastosować do czynności wykonywanych przez pomocników rolników? Pomoc ze swej istoty nie jest działaniem samoistnym, pozostaje w ścisłym skorelowaniu z działalnością podstawową, której jest wsparciem. Nie może być zatem wykonywana w dowolnym czasie. Co więcej - pomocnik rolnika podlega podporządkowaniu co do miejsca wykonywania umowy, albowiem zgodnie $\mathrm{z}$ art. 91a ust. 1 usr pomoc przy zbiorach jest wykonywana w określonym miejscu $\mathrm{w}$ gospodarstwie rolnika. Skoro pomocnik rolnika musi dostosować wykonywaną przez siebie pracę do określonego czasu i miejsca, nie sposób przypisać jego działaniom waloru samodzielności, który umożliwiałby

12 Por. Uzasadnienie projektu ustawy, mocą której rozszerzono stosowanie przepisów o minimalnym wynagrodzeniu na umowy zlecenia. Druk nr 600 Sejmu VIII kadencji.

13 A. Berezowski, Reforma sprzeczna z Konstytucja, „Tygodnik Solidarność” 2018, nr 14, s. 56 -57; B. Surdykowska, Kontrowersje wokół umowy o pomocy przy zbiorach, „Młody Jurysta” 2018, nr 3, s. 3, 12-13. 
gospodarowanie swoim czasem tak, aby gwarantował on odpowiednie do regeneracji, odpoczynku i załatwienia spraw osobistych przerwy w pracy.

Ustawodawca w żaden sposób nie uzasadnił aksjologicznego zróżnicowania sytuacji prawnej osób zatrudnionych $\mathrm{w}$ ramach umów o pomocy przy zbiorach względem innych osób wykonujących umowy cywilnoprawne o charakterze starannego działania czy też względem pracowników. Tym samym pokusić się można o stwierdzenie, że w sposób jaskrawy została naruszona zasada równego traktowania. Sytuacja faktyczna osób zatrudnionych przy zbiorach nie różni się bowiem tak znacznie od sytuacji faktycznej innych osób zarobkujących, aby w aż tak daleko idącym stopniu różnicować ich sytuację prawną.

\section{PODSUMOWANIE}

Ponieważ prawo nie działa w próżni, każdorazowo należy badać przełożenie jego konstrukcji na rzeczywiste stosowanie. Zgodnie z danymi uzyskanymi z KRUS przez KK NSZZ „Solidarność” 14 w pierwszym roku obowiązywania regulacji prawnej w zakresie umowy o pomocy przy zbiorach zawarto 64915 takich umów. Tym samym, w zależności od przyjętej optyki, można optymistycznie stwierdzić, że zawarto o 64915 umów o dzieło mniej ${ }^{15}$. Można też pesymistycznie dowodzić, że zawarto o 64915 umów zleceń bądź umów o pracę mniej ${ }^{16}$. Przepisy kodeksu pracy w art. $25^{1} \S 4$ pkt 2 dopuszczają wyjątek w postaci limitowania okresów zatrudnienia na podstawie umów o pracę na czas określony odnośnie do umów zawartych w celu wykonywania pracy o charakterze dorywczym lub sezonowym, jeżeli ich zawarcie $\mathrm{w}$ danym przypadku służy zaspokojeniu rzeczywistego okresowego zapotrzebowania $\mathrm{i}$ jest niezbędne w tym zakresie $\mathrm{w}$ świetle wszystkich okoliczności zawarcia umowy. Praca przy zbiorach zdaje się wręcz akademickim przykładem stosowania tych regulacji. W takim stanie rzeczy trudno znaleźć racjonalne uzasadnienie preferowania przez ustawodawcę zawierania umów o pomocy przy zbiorach zamiast umów o pracę.

Taki kierunek ustawodawstwa pozostaje w sprzeczności z założeniami europejskiego filaru praw socjalnych ${ }^{17}$, który nie tylko spina istniejące dotąd zasady związane z unijną polityką społeczną, lecz także wyznacza jej nowe kierunki. Zgodnie $\mathrm{z}$ jego postanowieniami osoby zatrudniane (określane mianem workers) mają prawo między innymi do sprawiedliwego i równego traktowania w odniesieniu do warunków pracy, dostępu do ochrony socjalnej. Co więcej, postanowienia

14 Pismo z dnia 11 stycznia 2019 roku, 0000-U B.0361.23.2019.

15 Optymizm związany jest z tym, że umowy o dzieło poczytywane są jako mniej korzystne dla osób zatrudnionych od umów o pomocy przy zbiorach.

16 Pesymistyczne jest, że dla osób zatrudnionych korzystniej byłoby zawrzeć umowę zlecenia albo umowę o pracę.

17 O relacji umowy o pomocy przy zbiorach do EFPS B. Surdykowska, op. cit., s. 13 n. 
EFPS przewidują, że należy zapobiegać powstawaniu stosunków pracy prowadzących do niepewnych warunków pracy, w tym przez wprowadzenie zakazu nadużywania nietypowych umów o pracę. Skoro filar wprowadza taką regulację w odniesieniu do nietypowego zatrudnienia pracowniczego, zgodnie $\mathrm{z}$ argumentum a maiori ad minus, tym bardziej należy przeciwdziałać nadużywaniu stosunków zatrudnienia, które nie tylko nie gwarantują stabilizacji zatrudnienia, lecz także nie skutkują nawiązaniem stosunku pracy. Wprowadzając regulację prawną związaną z umową o pomocy przy zbiorach, polski ustawodawca realizuje postanowienia EFPS w sposób dokładnie przeciwny od wymaganego.

\title{
THE HARVEST HELP CONTRACT - A NEW LEGAL BASIS OF EMPLOYMENT
}

\begin{abstract}
Summary
The labour market policy that has been developed in previous years seems to promote employment based on the labour law relationship over civil law employment. The exact opposite direction is set out by the introduction of the harvest help contract. The rationality of its introduction into the legal system is explained by economic reasons - the need to help farmers with jobs which are characterized by increased seasonal intensity. Therefore, it is important to discuss the scope of its application (both in terms of subject and object matter) and the conditions under which farmers' helpers should provide their work. Their differentiation of the working conditions in comparison to other employed persons should be rationally justified by axiological reasons.
\end{abstract}

Keywords: harvest help contract, farmer's assistant, disintegration of labour protection, civil law employment

\section{BIBLIOGRAFIA}

Berezowski A., Reforma sprzeczna z Konstytucja, „Tygodnik Solidarność” 2018, nr 14.

Florczak I., Status prawny osób świadczacych pracę w ramach umownego zatrudnienia nietypowego, Łódź 2017.

Florczak I., Zatrudnienie jako kategoria prawna, „Gdańsko-Łódzkie Roczniki Prawa Pracy i Prawa Socjalnego" 2013, nr 3.

Gersdorf M., Prawo zatrudnienia, Warszawa 2013.

Miąsko M., Analiza charakterystyki umowy o pomocy przy zbiorach (ujęcie komparatystyczne), „Studia z Zakresu Prawa Pracy i Polityki Społecznej” 25, 2018, nr 2.

Surdykowska B., Kontrowersje wokół umowy o pomocy przy zbiorach, „Młody Jurysta” 2018, nr 3. 